\title{
Pleural Sarcomatoid Mesothelioma
}

National Cancer Institute

\section{Source}

National Cancer Institute. Pleural Sarcomatoid Mesothelioma. NCI Thesaurus. Code C45663.

Malignant mesothelioma that arises from the pleura and is characterized by the presence of spindle-shaped cells forming fascicles, or that are distributed haphazardly resembling a sarcoma. 